Journal of Sustainability Perspectives

\title{
Green Room Circuit at Paulo VI Campus in Maranhao State University, Brazil
}

\author{
Andréa Aráujo do Carmo ${ }^{1,}{ }^{*}$, Kelly Fernanda de Sousa Santos ${ }^{2}$, Marcos Eduardo Miranda \\ Santos $^{3}$ \\ ${ }^{1,2}$ Maranhao State University, Cidade Universitária Paulo VI, Av. Lourenço Vieira da Silva, no 1000 - Bairro: \\ Jardim São Cristovão, CEP 65055-310 - São Luís/MA., Brazil \\ ${ }^{3}$ Maranhao Federal University, Cidade Universitária Dom Delgado, Av. dos Portugueses, 1966 - Bairro: \\ Bacanga, CEP: 65080-805 São Luís/MA, Brazil \\ * corresponding author: andreaaraujo@professor.uema.br
}

Article Info

Received:

15 March 2021

Accepted:

25 May 2021

Published:

1 August 2021

DOI:

Presented in The $6^{\text {th }}$ International (Virtual) Workshop on UI GreenMetric World University Rankings (IWGM 2020)

\begin{abstract}
The implementation of the Environmental Management Advisory at Maranhão State University, in 2015, promoted environmental education actions as a continuous in the institution, and coordinated by the Environmental Management System of the advisory. The approval on the call for the creation of Green Rooms, by the Ministry of Environment, became this university qualified in 2018 to have a Green Room in its space, constituting a space for environmental interactions. Thus, the objective was to discuss the actions developed in 2018. Having a Circuit format, the Green Room of this academy (Green Room Circuit at Paulo VI Campus), in the year in question, four visits were made, with activities scheduled in the Fishery and Aquatic Ecology laboratories, Zoology laboratory, Botanical Collection (Rosa Mochel), Agroecological Trail and seedling workshops. Totalizing 109 participants, 33\% were from the capital and 67\% from the metropolitan region of Sao Luis and other municipalities of Maranhão state, northeast of Brazil. Therefore, the Green Room Circuit of Paulo VI Campus was faced as a potentializer and dynamizer, for the development of actions that contribute to a sustainable awareness among its participants.
\end{abstract}

\section{Keyword:}

University. Sustainability. Education. Environment.

\section{Introduction}

The Constitution of the Federative Republic of Brazil states in its Art. 225 that Environmental Education (EA) is fundamental for the preservation of the environment, and must be worked across the different levels of education, encouraging the preservation of the environment [1]. The National Environmental Education Policy (PNEA), instituted by Law No. 9,795/99, also states that EA is an essential and permanent component in national 
education, both formal and non-formal [2].

With the implementation of the Environmental Management Advisory (AGA) at the State University of Maranhão (UEMA), in 2015, the actions became systematic, continuous and aligned with the Environmental Agenda of Public Administration of the Environment Ministry [3], which is the guiding document of the institution's Environmental Management System (SGA).

In parallel, MMA instituted the Green Rooms Project in order to encourage the implementation of socioenvironmental spaces that develop innovative and dynamic actions in order to awaken in the participants, an ecological awareness and consequently, the reflection on their responsibility facing the changes on society [4].

Maranhão State University (UEMA), recognizing the importance of Green Rooms as spaces of environmental awareness for teaching in the country, applied and was approved in the Call no 01/2017 of MMA [5], for the implantation of one of those spaces in its headquarters campus (Paulo VI Campus), located in São Luis city, capital of Maranhão state. In 2018, the Green Room was inaugurated and since then, with multidisciplinary visits, in teaching and research laboratories of Biological Sciences Course, ecological and interpretive trails, carried out by teachers and students, AGA collaborators, composed the "Green Room Circuit at Paulo VI Campus". Therefore, the objective was to describe the actions carried out in 2018 and to analyze the perceptions of public satisfaction after participation in the Green Room Circuit at Paulo VI Campus, located in Sao Luis city /Maranhão.

\section{Methodology}

\subsection{The Green Room Circuit}

The target audience of the "Green Room Circuit at Paulo VI Campus" are schools of different levels of education (elementary, secondary, technical and higher) in Maranhão (capital and state interior). It is necessary that a representative of the educational institution that wishes to participate in the Circuit, make a previous appointment through the AGA's institutional email, informing the name of the institution, the number of students who will participate in the activities, preferred shift to participate and activities of interest. From this point, a specific script is built for the institution.

The Circuit consists of five dynamic and successive stages, two of which are required and three are optional (selection of one or two activities offered) (Figure 1A). The starting point is the UEMA Green Room where the participating school is hosted and presented, and is therefore a mandatory stage (Figure 1B). The second stage consists on a visit to the Teaching and Research Laboratories of Biological Sciences Course at UEMA (optional stage), where scientific and didactic exhibitions are held (Figure $1 \mathrm{C}$ ).

In the third stage (optional), a visit is made to the university forest, where leisure activities, competitions, environmental dynamics and gardening are carried out (Figure 1D). The fourth stage (optional) is developed at the School Farm of São Luís (supplementary sector of UEMA's Center for Agricultural Sciences, that aims to assist in the development of practical teaching, research and extension activities [6]), where there are agro-ecological trails, seedling production and composting workshop (Figure 1E). Finally, in the last (mandatory) step, a diagnostic evaluation is accomplished, about the satisfaction of the Circuit participants, through questionnaires with five objective questions, generating a quantitative and qualitative report of these data obtained and filed in the advisory database (Figure 1F). 

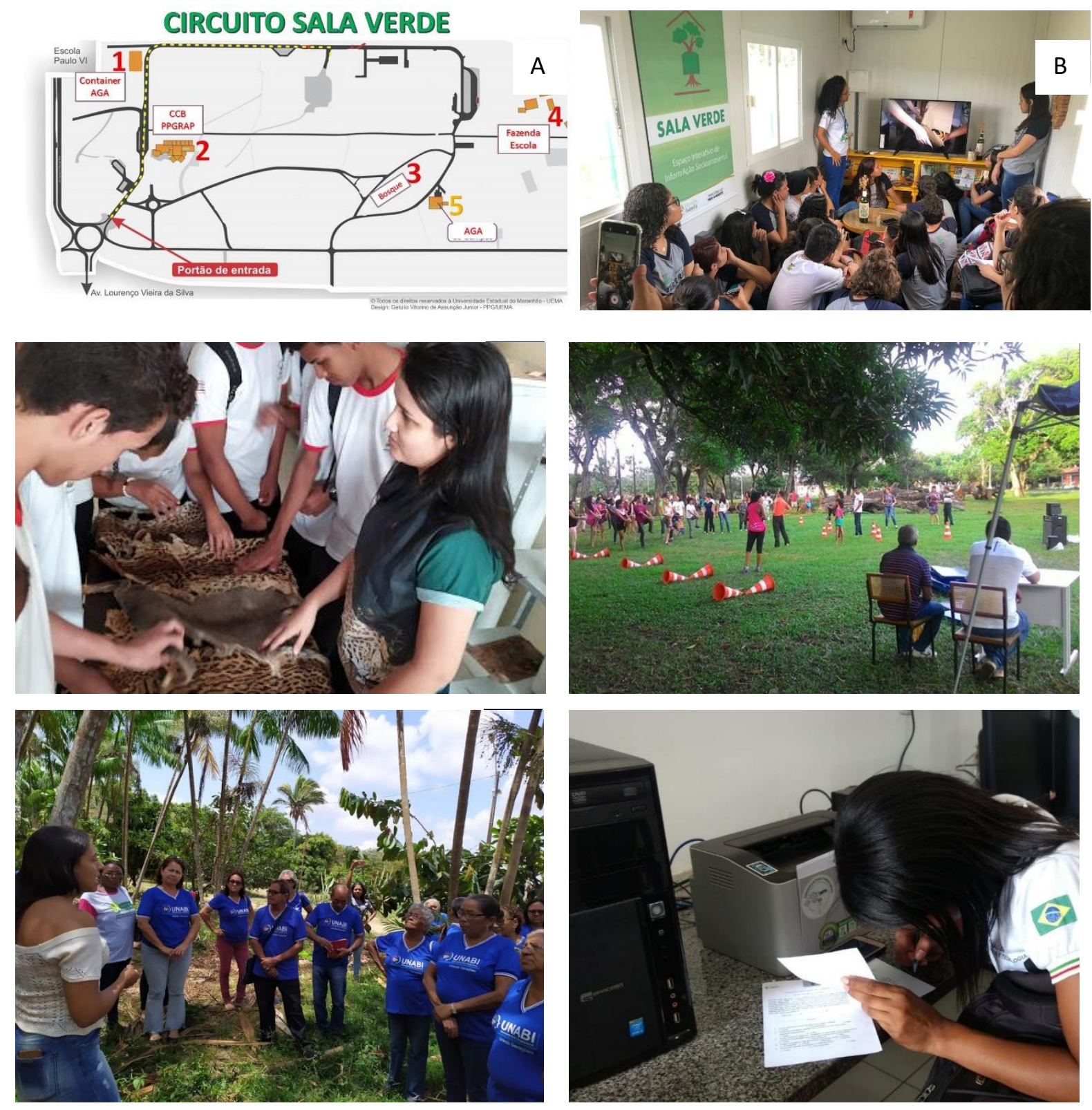

Figure 1. Steps of Green Room Circuit at Paulo VI Campus.

(A) Schematic drawing of the circuit stages.; (B) Beginning of the Circuit in UEMA's Green Room; (C) Didactic exhibition at Zoology Laboratory of Biological Sciences Course; (D) Visit to the institution's forest; (E) Agroecological trail at School Farm; (F) Application of diagnostic questionnaire.

SOURCE: AGA collection, 2020.

\subsection{Data analysis}

This study has a descriptive character and used the participation indicators in each Circuit as data, compiled at the end of each visit and deposited in AGA's database. These data were divided into two categories: 1) Summary of participation in the Circuit and 2) Diagnosis of perception and satisfaction of the participants. The data were analyzed (tabulation and percentage) with the aid of the Excel Program, of the Microsoft Office package (version 2019). 


\section{Results \& Discussion}

\subsection{Summary of participation in the Circuit}

During 2018, four circuits were held with schools of different levels of education, in the period from July to December. In total, 109 visitors participated, with ninety-one percent $(91 \%)$ students and nine percent $(9 \%)$ teachers. As for the origin, from São Luís thirty-three percent (33\%) (capital of the state of Maranhão), and sixty-seven percent (67\%) of residents of the metropolitan region of São Luís (Alcântara) and from the state (Barreirinhas, located in the east of the state). The developed activities were: seedling workshops, agroecological trails and exhibitions of biological collections (zoological and botanical) (Table 1).

Table 1. Summary of the developed circuits in 2018.

\begin{tabular}{|c|c|c|c|c|}
\hline $\begin{array}{l}\text { Circuit } \\
\text { Number }\end{array}$ & $\begin{array}{l}\text { Institution/Lev } \\
\text { el of Education } \\
\text { of the } \\
\text { participating } \\
\text { classes }\end{array}$ & Municipality & $\begin{array}{c}\text { Number of } \\
\text { participants } \\
\text { ( } \mathrm{A}=\text { Students } \\
/ \\
\mathrm{P}=\text { Teachers) }\end{array}$ & Developed Activities \\
\hline 1st & $\begin{array}{l}\text { Scout's School } \\
\text { of } \\
\text { Maranhão/Elem } \\
\text { entary School }\end{array}$ & São Luís & $16(14 \mathrm{~A} / 2 \mathrm{P})$ & $\begin{array}{l}\text { Exhibition of the Green } \\
\text { Room's dynamics; } \\
\text { Conversation about the } \\
\text { importance of fishing } \\
\text { resources (Laboratory of } \\
\text { Fisheries and Aquatic Ecology); } \\
\text { Exhibition of the Botanical } \\
\text { Collection (Rosa Mochel); } \\
\text { Seedling } \\
\text { workshop; } \\
\text { Application of questionnaires. }\end{array}$ \\
\hline 2nd & $\begin{array}{l}\text { Federal } \\
\text { Institute of } \\
\text { Maranhão } \\
\text { (IFMA) } \\
\text { Alcântara } \\
\text { Campus / High } \\
\text { and Technical } \\
\text { Education. }\end{array}$ & Alcântara & $27(25 \mathrm{~A} / 2 \mathrm{P})$ & $\begin{array}{l}\text { Exhibition of the Green } \\
\text { Room's dynamics; } \\
\text { Agroecological Trail (School } \\
\text { Farm of São Luís); } \\
\text { Conversation about the } \\
\text { importance of fishing } \\
\text { resources (Laboratory of } \\
\text { Fisheries and Aquatic Ecology); } \\
\text { Application of the } \\
\text { questionnaires. }\end{array}$ \\
\hline
\end{tabular}




\begin{tabular}{|c|c|c|c|c|}
\hline $3 r d$ & $\begin{array}{l}\text { Federal } \\
\text { Institute } \\
\text { Maranhão } \\
\text { (IFMA) } \\
\text { Barreirinhas } \\
\text { Campus / High } \\
\text { School. }\end{array}$ & Barreirinhas & $43(40 \mathrm{~A} / 3 \mathrm{P})$ & $\begin{array}{l}\text { Exhibition of the Green } \\
\text { Room's dynamics; } \\
\text { Exhibition of the Zoological } \\
\text { Collection (Laboratory of } \\
\text { Zoology); } \\
\text { Application of the } \\
\text { questionnaires. }\end{array}$ \\
\hline 4th & $\begin{array}{l}\text { Federal } \\
\text { Institute of } \\
\text { Maranhão } \\
\text { (IFMA) - } \\
\text { Barreirinhas } \\
\text { Campus / } \\
\text { Higher } \\
\text { Education }\end{array}$ & Barreirinhas & $23(20 \mathrm{~A} / 3 \mathrm{P})$ & $\begin{array}{l}\text { Exhibition of the Green } \\
\text { Room's dynamics; } \\
\text { Exhibition of the Botanical } \\
\text { Collection (Rosa Mochel); } \\
\text { Agroecological Trail (School } \\
\text { Farm of São Luís). }\end{array}$ \\
\hline
\end{tabular}

As noted (Table 1), the laboratories that developed activities with themes related to Zoology and Botany, were the most requested, as they were the contents being studied in the semester. The biological collections present in the laboratories (Zoology and Botany) works as an attraction for Science and Biology classes, as it allows the student to have visual and manual contact with the worked biological taxon, being able to visualize morphological structures that characterize and differentiate them [7].

The use of pedagogical spaces that allow the junction between practical classes and awareness of environmental issues has proved to be a highly efficient methodology in the teaching-learning process [8], a process called Vigotsy as a social interactionist theory (exchange of information and experiences) responsible for forming a way of learning in the individual [9].

Pedagogical practices should stimulate and make a constant relationship between critical thinking and a sense of environmental responsibility, based on a conscious and sustainable vision, with actions that allow changes in habits, attitudes and social practices in the current generation [10].

\subsection{Diagnosis of participant's perception and satisfaction}

Regarding the participant's perception of satisfaction, when asked if the Circuit was developed in a clear and playful way and if this activity would be recommended as an extraclass activity, one hundred percent $(100 \%)$ of the respondents answered "yes" to both questions. When asked about the importance as a way of promoting sustainable actions at this university, only two percent (2\%) disagreed. Seventy-eight percent $(78 \%)$ of the participants categorized the activities as excellent and twenty two percent (22\%) good. Regarding the execution of objectives, ninety eight percent $(98 \%)$ stated that it corresponded to the presented objectives (Table 2). 
Table 2. Perception of participant's satisfaction.

\begin{tabular}{|c|c|}
\hline QUESTIONS & PERCENTAGE \\
\hline $\begin{array}{l}\text { The Circuit is developed in a } \\
\text { clear and playful way? }\end{array}$ & YES $=100.00 \%(109 / 109)$ \\
\hline $\begin{array}{l}\text { Would you recommend this activity to a } \\
\text { school as an extra-class activity? }\end{array}$ & YES $=100.00 \%(109 / 109)$ \\
\hline $\begin{array}{l}\text { Do you agree that this activity is important } \\
\text { to include and boost the community in the } \\
\text { university's sustainable actions? }\end{array}$ & $\begin{array}{l}\text { YES }=98.00 \%(107 / 109) \\
\text { NO }=2.00 \%(2 / 109)\end{array}$ \\
\hline $\begin{array}{l}\text { What did you think about the } \\
\text { environmental activities developed in this } \\
\text { circuit? }\end{array}$ & $\begin{array}{l}\text { EXCELLENT }=78.00 \%(85 / 109) \\
\text { GOOD }=22.00 \%(24 / 109)\end{array}$ \\
\hline $\begin{array}{l}\text { Does the circuit serve the established } \\
\text { objectives? }\end{array}$ & $\begin{array}{l}\mathrm{YES}=98.00 \%(107 / 109) \\
\mathrm{NO}=2.00 \%(107 / 109)\end{array}$ \\
\hline
\end{tabular}

Activities that escape the routine of the classroom tend to be well accepted and well assimilated by the students, especially, when are tasks based on active teaching and learning methodologies are applied, which allow the student to be the protagonist and responsible for his learning, being the teacher the agent promoting the movement between what is already known for what tends to be acquired, and the exchange of knowledge between students [11].

Extra-class activities, which range from school celebrations to school trips, are extremely important as teaching methodologies, as they reflect both on the integration of the school community and on the revision of the contents that are worked on in the classroom, thus being a complementary learning process [12].

\section{Concluding Remarks}

The Green Room Circuit at Paulo VI Campus has been, in the basic education of São Luís and the municipalities of the state, an alternative place of experiences and even support for needy schools that do not have laboratories in their physical structure and living spaces, making many of its spaces, places of practical classes and possible school extensions of teaching units, near the university. In this way, it has become a socio environmental and educational space for teaching in the state of Maranhão, with national repercussions.

\section{References}

1. Brasil, 1988. ARTIGO 225, CAPITULO VI de 22 de setembro de 1988. CAP VI MEIO AMBIENTE. Definições, Brasília, DF. Available online at: http://www.planalto.gov.br/ccivil 03/constituicao/constituicao.htm. Access in: sept 1st, 2020.

2. Brasil, 1999. DECRETO № 9.795, DE 27 DE ABRIL DE 1999. Política Nacional de Educação Ambiental. Definições, Brasília, DF. Available online at: http://www.planalto.gov.br/ccivil 03/leis/19795.htm. Access in: sept 1st, 2020.

3. Brasil, 2009. Ministério do Meio Ambiente. Agenda Ambiental na Administração Pública (A3P). Brasília - DF. 95p. Available online at: 
https://www.mma.gov.br/estruturas/a3p/ arquivos/cartilha a3p 36.pdf. Access in: sept 1st, 2020.

4. Brasil, 2020. Ministério do Meio Ambiente. Projeto das salas verdes. Brasília, DF. Available online at: http://salasverdes.mma.gov.br/sobre-o-projeto/. Access in: sept 1st, 2020.

5. Brasil, 2017. Ministério do Meio Ambiente. Secretária de Articulação Institucional e Cidadania Ambiental. Chamada no01/2017 - Criação de Novas Salas Verdes. Brasília DF. Available online at: http://salasverdes.mma.gov.br/wpcontent/uploads/2019/06/Chamada-Projeto-Salas-Verdes-2017.pdf. Access in: sept 1st, 2020.

6. Maranhão, 2020. Universidade Estadual do Maranhão.2020. Centro de Ciências Agrárias. Fazenda Escola de São Luís. São Luis - MA. Available online at: http://www.cca.uema.br/?page id=2577. Access in: sept 1st, 2020.

7. SANTOS, M. C., 2013. Coleções biológicas para o ensino de ciências: o herbário didático do Instituto de Aplicação da UERJ, Volume 26, pp. 12 - 18.

8. OLIVEIRA, F. R., PEREIRA, E. R., JÚNIOR, A. P., 2018. Horta escolar, educação ambiental e interdisciplinaridade. REVBEA, Volume 13, pp.10-31.

9. GOMES, Rolfi et al., 2010. Teorias de aprendizagem: pré concepções de alunos da área exatas do ensino superior privado da cidade de São Paulo. Scielo, Volume 16, pp 695708.

10. JACOBI, P. R., 2005. Educação ambiental: o desafio da construção de um pensamento crítico, complexo e reflexivo. Educação e pesquisa, Volume 31, pp. 233-250.

11. MOREIRA, J. R.; RIBEIRO, J. B. P., 2016. Prática pedagógica baseada em metodologia ativa: aprendizagem sobre a perspectiva do letramento informacional para o ensino na educação profissional. Períodico científico em outras palavras, Volume 12, pp. $93-114$.

12. OLIVEIRA, G. P., 2018. Atividades extraclasses e a importância de ir além da sala de aula. Revista Escritos e Escritas na EJA, n.10, pp. 58 - 66. 